\title{
Study into the COVID-19 Effects upon the North- Eastern Region Economy
}

\author{
Sibel Ahmedova* \\ Technical University of Varna, Department of Industrial Management, 1, Studentska str., Varna, \\ Bulgaria
}

\begin{abstract}
The primary objective of the present paper is to explore the impact of COVID-19 on the economy of the North-Eastern Region (NER) of the Republic of Bulgaria in an effort to systematize the appropriate mitigation measures to minimize the effects of COVID-19 outbreak. Determining the probable impact of the COVID-19 crisis on the NER economy is extremely difficult due to the pandemic dynamics and the constant shifts or changes in the forecasts related to its effects on the global economy and the development of the individual countries and regions in particular. The pandemic's impact on the NER economy is carefully considered in terms of regional GDP per capita analysis; the key indicators of the labour resources; the development of travel and tourism industry, information and communication technologies (ICT), manufacturing industry, trade industry, maritime industry, cultural and creative industries, the level of foreign direct investment (FDI).
\end{abstract}

\section{Introduction}

In the past year, the economies of the countries across the world were confronted with serious health and economic challenges as a result of the rapid development and viral spread of COVID-19 [2,3,6,8]. Restrictive measures were taken throughout Europe, including Bulgaria, to limit the coronavirus outbreak $[9,10,12]$. Indeed, the measures introduced were regarded as effective in safeguarding and preserving human lives but at the same time they led to a significant global slowdown in economic growth [1,4,5,7]. According to a study conducted by the Organisation for Economic Co-operation and Development (OECD), there was a substantial decline in the economic development over the past year even among the world's leaders such as China, Japan, the USA, the UK and others [13]. China's economy was the first to be affected by the development and spread of the virus, reporting a decline in its gross domestic product (GDP) by about 3,2\%. Despite the country's GDP increase in the last quarter of 2020, the achieved growth rate is still at its minimum values, in contrast with the corresponding pre-pandemic levels. The situation is also identical in countries such as Japan, where the country's GDP downturn is by $5 \%$; the USA by $9,1 \%$ and that of the UK by $9,5 \%$. Invariably, the slowdown in the world's largest economies is likely to have serious

* Corresponding author: sibel8386@gmail.com 
repercussions on the EU economy as well. For the first quarter of 2020, there was a decrease in the EU GDP by $3,2 \%$ as against the same period in 2019 . The largest falloff was reported by the economies of Spain by $22,1 \%$, Italy-by $17,7 \%$ and France-by $18,9 \%$. Only Germany reported a decline of around $11,3 \%$.

Clearly, the dynamic economic development of Bulgaria was also affected by the global pandemic. In the second quarter of 2020, the country's GDP was down by about $8,5 \%$ as compared to the same period in 2019 [11]. Nevertheless, the level of consumption remained the same, even a minimal growth was observed in the range of $0,4 \%$ on an annual basis. The underlying reasons for this are the measures taken to protect the jobs and preserve employment and maintain the salary levels in the private sector. The measures accomplished succeeded in holding back the sharp decline in income among the population and a significant decrease in household consumption expenditure. The high market uncertainty and the adverse business climate also have their consequences on the level of capital formation, which suffered a decline by about $14 \%$. As for the exports and imports of goods and services, there was a national-level decrease by $19,3 \%$ and $18,7 \%$, respectively. The flow of foreign direct investment also grew smaller by $26 \%$ in 2020 as opposed to 2019 , with a reported inflow of $14 \%$ relative to 2018 . The 2020 average industrial production index value dropped by $7 \%$, and the industrial turnover index fell by $8 \%$ in comparison with the one in the previous year.

\section{Study into the COVID-19 effects on the North-Eastern region (NER) economy}

Given the dynamic situation associated with the development and spread of the coronavirus, it is very difficult to determine its overall impact on the Bulgarian economy. The analysis of the COVID-19 effects on the NER economy is based on statistical data from the National Statistical Institute and a survey conducted among 72 enterprises situated on the territory of the region. The survey provides information on the changes in the labour resources, regional industrial development and the level of the foreign direct investments (FDI).

NER covers the districts of Varna, Dobrich, Shumen, Targovishte, and their 35 municipalities. Of all the regions in the country, NER is the region with the smallest area and ranks fourth in the formation of the country's GDP. Perceived, though, over the past few decades, has been the regional positive dynamics in the development of the country as a whole. However, the rapid rate of GDP growth per capita in the region has been disrupted by the emergence and spread of COVID-19, as is the case all over the world. The regional GDP per capita fell significantly over the past year mostly as a result of COVID-19 outbreak. The data reported in fig. 1 show that the largest decrease in the indicator is observed in Varna by nearly $11 \%$ compared to 2019 . The GDP slump per capita in Dobrich is $10,5 \%$ relative to that of 2019, while in Targovishte, the downtrend is by $9 \%$ compared to the previous year. Distinctive is the value of the GDP per capita in Shumen with its smallest relative differencearound $5 \%$. On the whole, Varna is the most affected area by the coronavirus pandemic in view of the fact that the normal functioning of the city's leading sectors -namely, the tourism and services sectors was severely interrupted. 


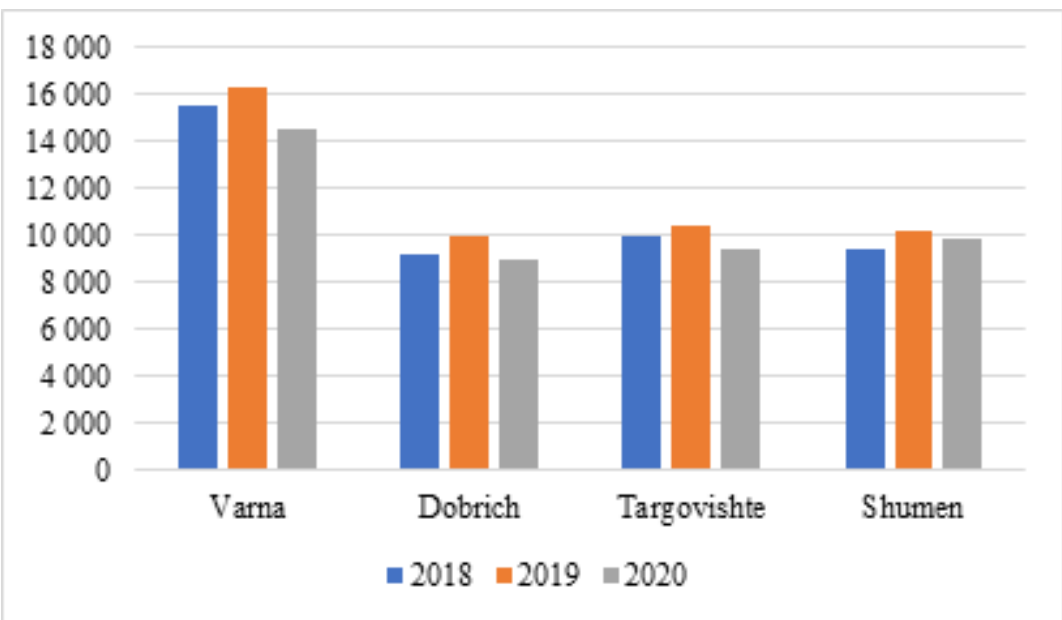

Fig.1. GDP per capita, BGN. [11]

The relatively small descent in the value of the GDP per capita in Shumen is stems from the fact that it is the industrial sectors that are predominant in the city. A significant proportion of businesses in the area had received subsidies and capital transfers, which enabled them to cushion the consequences of the curtailed economic activity upon the employment and collapsing labor share of income.

One of the most vulnerable sectors in NER is the tourism industry. Indeed, the researches undertaken in the region prove conclusively that the tourism industry is the most affected by the coronavirus pandemic (fig.2). As a result of the imposed restrictions and specific travel regulations, NER tourism sector admitted a plunge by almost $42 \%$ in its revenues.

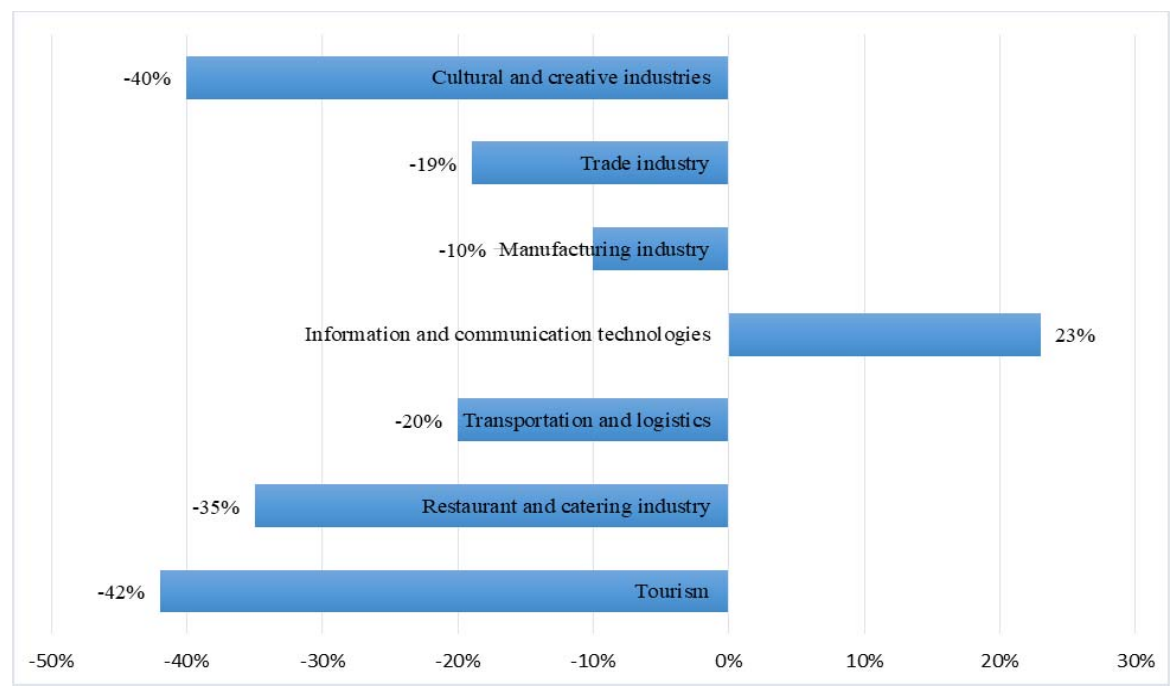

Fig. 2. COVID-19 effects upon NER economic activities [11]

The second most affected sector in the region is that of the cultural and creative industries, with a steep decline of $40 \%$. As recorded in fig. 2 , the restaurant and catering industry-wide revenues plummeted by $35 \%$, which is explained by the fact the respective establishments remained deserted under lockdown restrictions over a long period of time. With reference to 
the transportation and logistics activities, the reduction in revenue amounts to $20 \%$. Courier services are an exception to this trend and are, therefore, excluded from this category, since they reported increased volume of work and companies' revenues. Another sector heavily affected by COVID-19 is trade. The decline in revenues amounts to 19 per cent, while that in the manufacturing industry is about $10 \%$ as compared to 2019 . It is only the information and communication services sector that saw an increase of $23 \%$, which is attributable to the fact that most of these activities are carried out on the Internet. The financial sector and the educational service industries have fully re-organized their activities and workflow processes to be more effective and efficient in the Internet environment.

Considering the dramatic decline in the revenues of NER's individual sectors by their economic activities, the sharp rise in the unemployment rate across the region comes as no surprise (fig.3).

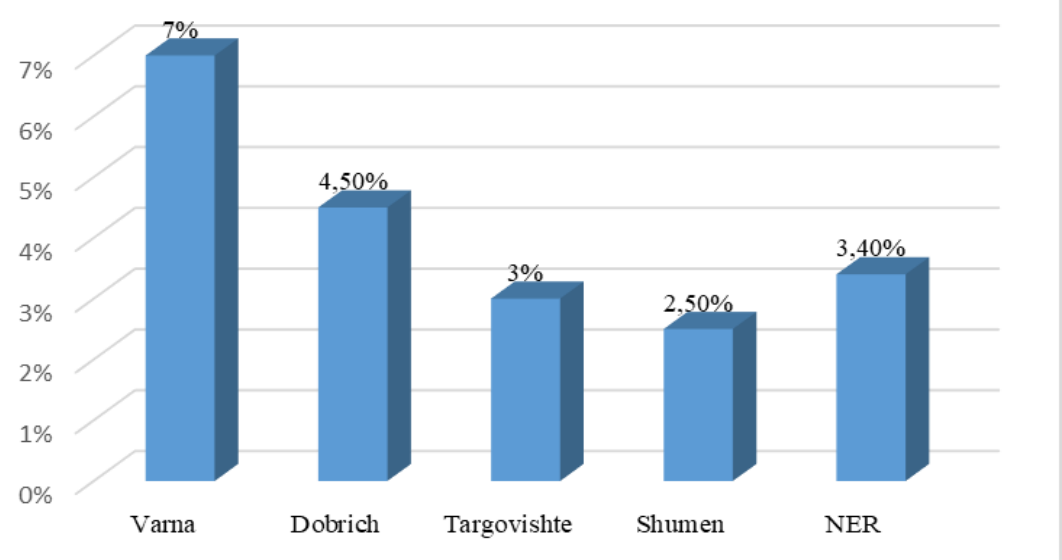

Fig. 3. Increase in NER unemployment rate (\%)

COVID-19 impact upon the economic activities has its adverse effects on the rate of unemployment at the regional district level. The most significant surge in the unemployment rate, for the past year, was observed in Varna - 7\%. And once again, this is due to the severe disruption in the normal functioning of the tourism industry and the services sector where a large proportion of the working-age population in the region is employed. The increase in the unemployment rate in Dobrich is $4,5 \%$, with the agricultural sector being the most vulnerable and severely affected. The introduced restrictive measures to the free movement of goods made the trade and export of the agricultural commodities practically impossible, which, in turn, triggered a reduction in the number of employees engaged in that sector. The unemployment rate in Targovishte went forward by 3\%, which is related more to the return migration of a significant number of overseas workers returning back to their home country, rather than to a drastic cut in the number of industry's jobs. Shumen stands out as a city with a relatively low proportion of increased unemployment rate- $2,5 \%$. Over the last year, the sharp rise in the unemployment rate across the entire NER territory was estimated an average of $3,40 \%$. The employment crisis, in view of the ongoing pandemic situation, domestic and world-wide, is projected to deepen significantly over the coming months. The unemployment rate in the region is believed to reach $6,9 \%$ by September 2021 , if the pandemic continues.

Another indicator adversely affected by COVID-19 is the amount of accumulated foreign direct investment (fig.4). 


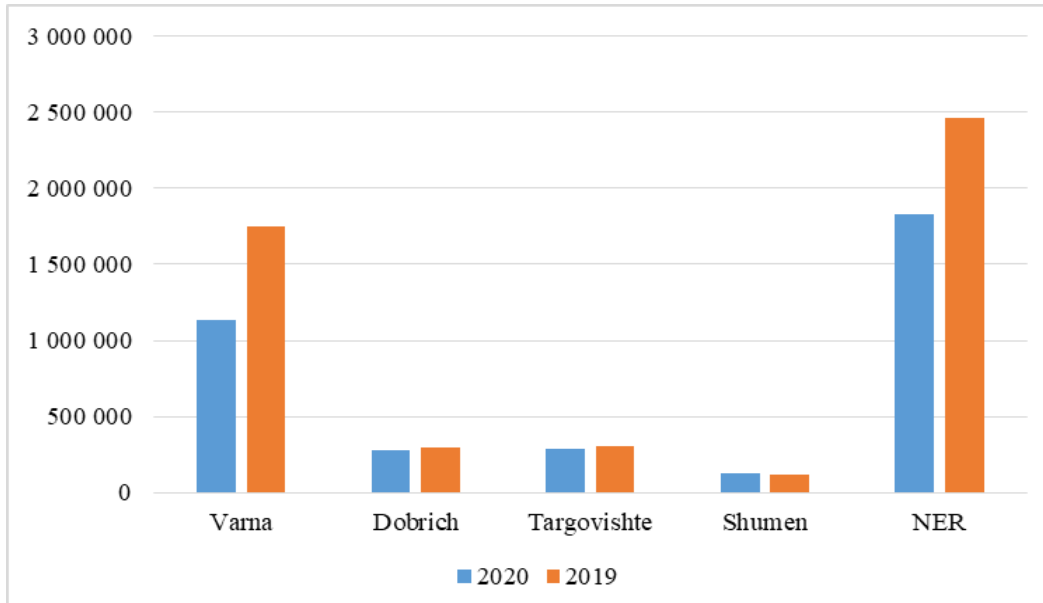

Fig. 4. COVID-19 impact upon the foreign direct investment in NER

The data from fig. 4 shows a substantial decrease in the absolute value of the foreign direct investments in the region under discussion. The most significant reduction in the value of investments by about $46 \%$ is registered in Varna in 2020 as against the investments made in 2019. The amount of foreign investments in Dobrich decreased by about $4,23 \%$ and in Targovishte- by $3,25 \%$. The only increase by $2,85 \%$ in the value of the foreign direct investments is recorded in Shumen, which is due to investment realization of activities launched in 2019 in the field of process manufacturing and machine building industries, the services sector and financial intermediation. All in all, throughout the entire North-Eastern region, the 2020 foreign direct investments fell by about $26 \%$, bringing, thus, their relative share closer to the levels of 1997 , when the country was experiencing a serious economic crisis.

\section{Possibilities for mitigating the effects of COVID-19 on NER's economy}

The presented analysis reveals a disturbing picture of the severe effects of COVID-19 on NER's economy over the past year. The decline in the number of foreign direct investments, the increase in the unemployment rate and the downturn in the GDP per capita are trends that will be observed in the years to come. Restoring not only the regional but also the national economy to pre-pandemic levels will be a lengthy long-term process requiring additional financial resources and anti-crisis measures. All these issues call for adequate public policies both at national and pan-European levels. About $85 \%$ of the surveyed enterprises indicate that the adopted measures prove to be insufficient, insubstantial and fail to achieve their objectives and produce the desired results. From this perspective, the State, including NER's local government, should focus their attention on the following courses of action to effectively mitigate the impact of COVID-19:

- developing a long-term strategy for the recovery of the most affected sectors by the pandemic;

- $\quad$ establishing an effective toolbox of crisis response measures for all the economic activities across the region;

- $\quad$ increasing the amount of State aid for the support of the most vulnerable sectors tourism, cultural and creative industries, restaurant businesses, transport sector, etc.; 
- developing a mechanism to ensure equality of treatment among the individual enterprises filing their applications for State's financial aid;

- $\quad$ extending the deadlines for annual financial statements for the enterprises and the respective payments of the tax liabilities;

- creating measures aimed at preserving the existing and creating new job opportunities;

- increasing the role of the Bulgarian Development Bank for the provision of liquid funds to the enterprises experiencing a shortage of financial resources;

- $\quad$ providing the opportunity for deferral of rent payment until after stabilization of the economic situation or payment at a lower rate;

- $\quad$ 'freezing' interest accrual on overdue rent payments.

This work was financially supported by grants from Bulgarian Science Fund and by the Bulgarian Ministry of Education and Science under the National Program for Research "Young Scientists and Postdoctoral Students", Technical University - Varna, 2021

\section{References}

1. Alexander W. Bartika, Marianne Bertrandb, Zoe Cullenc, Edward L. Glaeserd, Michael Lucac, Christopher Stanton, The impact of COVID-19 on small business outcomes and expectations, PNAS, pg. 17656-17666, (2020), https://doi.org/10.1073/pnas.2006991117

2. Alexander W. Bartik Marianne Bertrand Zoë B. Cullen Edward L. Glaeser Michael Luca Christopher T. Stanton, How are small businesses adjusting to covid-19? Early evidence from a survey, National Bureau Of Economic Research, (2020)

3. Ari Van Assche, Sarianna Lundan, Journal of International Business Policy 3, 273-279, From the editor: COVID-19 and international business policy, (2020)

4. Brent H. Meyer a, Brian Prescott, Xuguang Simon Sheng, International Institute of Forecasters, The impact of the COVID-19 pandemic on business expectations, (2021) https://doi.org/10.1016/j.ijforecast.2021.02.009 0169-2070/

5. https://www.irs.gov/pub/irs-soi/19rpgigworkreplacingtraditionalemployment.pdf

6. De Massis, A., Eddleston, K. A. and Rovelli, P., Journal of Management Studies, 'Entrepreneurial by design: How organizational design affects family and non-family firms' opportunity exploitation', , 1-36, (2020), https://doi.org/10.1111/joms.12568

7. Elgin, C., Basbug, G., \& Yalaman, A., Economic policy responses to a pandemic: Developing the COVID-19 economic stimulus index, VoxEU.org, https://voxeu.org/ article/economic-policy-responses-pandemic-covid-19- economic-stimulus-index

8. Ellul, I. Erel, U. Rajan, Rev. Corp. Finance Studys, The COVID-19 Pandemic Crisis and Corporate Finance, , 9 (3) (2020), pp. 421-429

9. Kilic, K., \& Marin, D., How COVID-19 is transforming the world economy. VoxEU.org, May 10: https://voxeu.org/ article/how-covid-19-transforming-world-economy, (2020)

10. Li, H., \& Sheng, X. S., Applied Economics Let Dating COVID-induced recession in the U.S.., (2020).

11. National Statistical Institute

12. Stephen Brammer, Layla Branicki, Martina K. Linnenluecke, Academy of Management PerspectivesVol. 34, No. 4, COVID-19, Societalization, and the Future of Business in Society, (2020)

13. OECD employment outlook 2020, Worker security and the covid-19 crisis, (2020) 